\title{
Clinical and Molecular Features of Our Pompe Patients: Single-Center Experience
}

\section{Pompe Tanısı Alan Hastalarımızın Klinik ve Moleküler Özellikleri: Tek Merkez Deneyimi}

\author{
Melis Köse ${ }^{1 \oplus}$, Engin Köse ${ }^{2 \oplus}$, Mehtap Kağnıci ${ }^{2}$, Aycan Ünalp ${ }^{3 \oplus}$, Ünsal Yılmaz ${ }^{3} \odot$ \\ Murat Muhtar Yılmaz ${ }^{4} \oplus$, Timur Meşe ${ }^{4} \odot$, Selvinaz Edizer $^{3} \oplus$, Semra Gürsoy ${ }^{5} \oplus$, Hüseyin Onay ${ }^{6} \odot$ \\ Eser Sözmen Yıldırım ${ }^{7}$
}

${ }^{1}$ Izmir Katip Çelebi University Medical Faculty, Department of Pediatrics, Division of Inborn Errors of Metabolism, Izmir, Turkey ${ }^{2}$ Health Sciences University, Behçet Uz Children Hospital, Division of Inborn Errors of Metabolism, Izmir, Turkey

${ }^{3}$ Health Sciences University, Behçet Uz Children Hospital, Department of Child Neurology, Izmir, Turkey

${ }^{4}$ Health Sciences University, Behçet Uz Children Hospital, Department of Child Cardiolology, Izmir, Turkey

${ }^{5}$ Health Sciences University, Behçet Uz Children Hospital, Department of Child Genetics, Izmir, Turkey

${ }^{6}$ Ege University Medical Faculty, Department of Medical Genetics, Izmir, Turkey

${ }^{7}$ Ege University Faculty of Medicine, Department of Biochemistry, Division of Clinical Chemistry, Izmir, Turkey

Received: 20 February 2020 / Accepted: 02 March 2020 / Publication date: 26 March 2020

Cite as: Köse M, Köse E, Kağnıcı M, Ünalp A, Yılmaz Ü, Yılmaz MM, Meşe T, et al. Clinical and molecular features of our pompe disease patients: A single-center experience. Med J Bakirkoy 2020;16(1):49-55

\section{ABSTRACT}

Introduction: Pompe disease (PD), glycogen storage disease Type II (GSD II), is an autosomal recessive inherited lysosomal storage disease caused by pathogenic variants in the GAA gene that encodes lysosomal acid $\alpha$-glucosidadase (GAA) enzyme. The incidence of the disease varies from country to country. PD is mainly presents as two groups of phenotypes as infantile-onset Pompe disease (IOPD) and late-onset Pompe disease.

Objective: The aim of this study is to discuss the molecular and clinical characteristics of infantile-onset Pompe disease (IOPD) and late-onset pompe disease (LOPD) followed-up in our center.

Method: A total of 10 patients diagnosed with IOPD and 4 patients diagnosed with LOPD in Izmir Dr. Behcet Uz Pediatric Health and Diseases and Surgery Training and Research Hospital Pediatric Metabolism Unit between 06.01.2015 and 06.01. 2019 were included in the study. The patients' demographic characteristics, clinical findings at the time of diagnosis and during the folllow-up period, biochemical findings, muscle biopsy data, results of enzymatic analyses and moleculargenetic characteristics were recorded retrospectively.

Results: $A$ total of 10 patients were included in the study. 7 patients were diagnosed with IOPD and 3 patients with LOPD. The median follow-up period of all patients was 26 months (range: 6-42 months). The c.896 C>T (8/32, 25\%) is detected as the most common variant. 1237G>T (p.Asp413Tyr), c.2019 C>A (p.Asn673Lys), c.418A>T (p.Asn140Tyr) variants were detected for the first time.

Conclusion: Pompe disease is one of the most important congenital metabolic diseases in which early diagnosis and treatment are of great importance. Despite the significant improvement in disease prognosis with the introduction of enzyme replacement therapy, there are still patients with poor prognosis despite early diagnosis. Phenotype-genotype studies are crucial in this respect.

Keywords: Pompe disease, hypertrophic cardiomyopathy, hypotonicity

öz

Giriş: Pompe hastalığı (PD), glikojen depo hastalığı Tip II (GSD II), lizozomal acida-glucosidadase (GAA) enzimini kodlayan GAA genindeki patojenik varyantlar sonucu ortaya çıkan otozomal resesif kalıtımlı lizozomal depo hastalığıdır. Hastalığın sıkığı ülkeden ülkeye değișmektedir. Temel olarak erken bașlangıçlı pompe hastalı̆̆ı (IOPD) ve geç başlangıçı pompe hastalığı (LOPD) olmak üzere iki gruba ayrılır.

Amaç: Çalısmamız, merkezimizde izlenen LOPD hem IOPD hastalarının moleküler ve klinik özelliklerinin tartısılmasını amaçlamaktadır.

Yöntem: Çalısmamıza 01.06.2015-01.06.2019 tarihleri arasında izmir Dr.Behçet Uz Çocuk Sağlığı ve Hastalıkları ve Cerrahisi Eğitim Arastırma Hastanesi Çocuk Metabolizma Ünitesi'nde IOPD hastalığı tanısı alan toplam 10 hasta ve LOPD tanısı alan 4 hasta dahil edilmiştir. Hastaların retrospektif olarak demografik özellikleri, tanı anındaki ve izlem sırasındaki klinik bulguları, biyokimyasal bulguları, kas biyopsisi verileri, enzimatik analiz sonuçları ve moleküler-genetik özellikleri kayit altına alındı.

Bulgular: Çalışmamıza toplam 10 hasta dahil edilmiștir. 7 hasta IOPD, 3 hasta LOPD tanısı almıștır. Tüm hastaların izlem süresi median 26 ay (range: 6-42 ay) olarak saptanmıştır. En sık görülen varyant c.896 C>T (8/32, \%25) olarak saptanmıştır. 1237G>T (p.Asp413Tyr), c.2019 C>A (p.Asn673Lys), c.418A>T (p.Asn140Tyr) varyantları ilk kez saptanmıștır.

Sonuç: Pompe hastalığı erken tanı ve sonuç olarak tedavinin büyük önem tassıdığı doğumsal metabolik hastalıkların başında gelmektedir. Enzim replasman tedavisinin kullanıma girmesi ile hastalık prognozunda belirgin düzelme olmakla birlikte erken tanıya rağmen halen prognozu kötü giden hastalar bulunmaktadır. Fenotip-genotip çalışmaları bu açıdan önem taşımaktadır.

Anahtar kelimeler: Pompe hastalığı, hipertrofik kardiyomyopati, hipotonisite

Corresponding Author:

drmelisdemir@gmail.com
M. Köse 0000-0003-2255-3725

E. Köse 0000-0001-7238-2894

M. Kağnıcı 0000-0002-7071-9200

A. Ünalp 0000-0002-3611-5059

Ü. Yılmaz 0000-0002-7256-8557

M. M. Yılmaz 0000-0003-0819-5829
T. Meşe 0000-0002-4433-3929

S. Edizer 0000-0002-8846-383X

S. Gürsoy 0000-0002-6795-3012

H. Önay 0000-0002-0584-8866

E. Sözmen Yıldırım 0000-0002-6383-6724

(c) Telif hakkı Sağlık Bilimleri Üniversitesi Bakırköy Dr. Sadi Konuk Eğitim ve Araştırma Hastanesi'ne aittir. Logos Tıp Yayıncılık tarafindan yayınlanmaktadır. Bu dergide yayınlanan bütün makaleler Creative Commons Atff-GayriTicari 4.0 Uluslararası Lisansı ile lisanslanmıştr.

(C) Copyright Health Sciences University Bakırköy Sadi Konuk Training and Research Hospital. This journal published by Logos Medical Publishing.

Licenced by Creative Commons Attribution-NonCommercial 4.0 International (CC BY-NC 4.0) 


\section{INTRODUCTION}

Pompe disease (PD), or glycogen storage disease Type II (GSD II), is an autosomal recessive inherited lysosomal storage disease caused by pathogenic variants in the GAA gene that encodes Ilysosomal acid $\alpha$-glucosidadase (GAA) enzyme ${ }^{(1)}$. The GAA gene is a typical housekeeping gene expressed in all cell types. Pathogenic variants in the GAA gene are present in all cell types, but some organs and functions are affected more strongly. Skeletal muscle and heart muscle are the primarily affected tissues (2).

The prevalence of PD varies in different ethnic groups according to clinical forms. The incidence of rapidly progressive infantile-onset pompe disease (IOPD) was $1 / 138000$ in Caucasian race and 1/30000 in Taiwan ${ }^{(3)}$. The clinical classification of PD is based on the age and progression of the disease. PD is presented in two main groups as infantile-onset Pompe disease (IOPD) and late-onset Pompe disease (LOPD). Classical IOPD or rapidly progressive IOPD is a progressive disease presenting within the first few days to several weeks of life with severe cardiomyopathy, respiratory failure and death in the first few years of life. Non-classical IOPD occurs in the first year of life and cardiomyopathy is milder compared to classical IOPD. However, muscle weakness is significant and in untreated cases respiratory failure occurs in early childhood ${ }^{(3,4)}$. The $28 \%$ of PD cases were IOPD and $85 \%$ of them were shown to be classical IOPD ${ }^{(5)}$. Clinical findings of Pompe disease develops due to GAA activity decreasing to less than $30 \%{ }^{(1)}$. Classical IOPD occurs when enzyme activity is less than $1 \%$ of normal ${ }^{(6)}$. LOPD occurs after infantile period; while onset of the clinical findings may vary from the first to the sixth decades of life ${ }^{(7)}$. Clinical presentation in LOPD can be seen as limb-girdle muscular dystrophy or severe respiratory muscle weakness that require treatment with mechanical ventilation. Heart muscle is rarely affected in this group ${ }^{\left({ }^{(8)}\right.}$.

In 2006, enzyme replacement therapy (ERT) with recombinant human acid $\alpha$-glucosidase (rhGAA; alglucosidase alfa ${ }^{\odot}$; Myozyme $^{\odot}$, Lumizyme $^{\odot}$, Genzyme Corporation, Cambridge, MA) was introduced. Although the natural course of the disease changes with ERT; $51 \%$ of patients become ventilator depen- dent before age $3^{(9)}$. The effective dose of ERT remains controversial. There is information in the literature on the use and efficacy of doses ranging from $20 \mathrm{mg} /$ $\mathrm{kg}$ / every other week (eow) to $40 \mathrm{mg} / \mathrm{kg} /$ week $^{(9,10)}$. There are many conditions that influence the efficacy of ERT other than its dosage, but one of them is undoubtedly the cross-reacting immunologic material (CRIM). It is known that CRIM-negative patients demonstrate much weaker response to ERT compared to CRIM-positive patients ${ }^{(11-14)}$. However, the fact that CRIM is not available in all centers and that the results come from overseas centers pose significant difficulties in the decision-making process.

The aim of this study is to discuss clinical follow-up, molecular genetic characteristics and phenotypegenotype relationships of 10 patients with IOPD and LOPD.

\section{MATERIALS and METHODS}

\section{Patient Selection}

A total of 7 patients diagnosed with IOPD and 3 patients with LOPD in Izmir Dr. Behcet Uz Pediatric Health and Diseases and Surgery Training and Research Hospital Pediatric Metabolism Unit between 06.01.2015 and 06.01. 2019 were included in the study. The patients' demographic characteristics, clinical findings at the time of diagnosis and over the folllow-up period, biochemical findings, results of enzymatic and molecular-genetic analysis were recorded retrospectively.

\section{Lysosomal acid $\alpha$-glucosidadase (GAA) measure- ment}

Lysosomal acida-glucosidadase activity was measured with UHPLC MS/MS method (Orsini JJ) in dry blood and leukocytes (Waters Acquity ${ }^{\mathrm{TM}}$ UPLC I-Class system). The substrate was provided by CDC ${ }^{(15)}$.

\section{GAA mutation analysis}

GAA mutation analyses were performed in 10 patients with highly suspected PD. DNA was extracted from $2 \mathrm{ml}$ EDTA containing peripheral blood samples using QIAamp DNA Mini Kit in accordance with the manifacturer's instructions. The full coding sequen- 
ces of the GAA gene (NCBI: NT024871) were amplified and sequenced. The most likely disease-causing variants, identified by data analysis, were confirmed using Sanger sequencing method. Segregation analysis was then performed.

\section{RESULTS}

\section{Demographic Findings and Clinical Features}

The clinical characteristics of our patients are summarized in Table 1. A total of 10 patients were included in the study. Seven patients were diagnosed with IOPD and 3 patients with LOPD. The median follow-up period of all patients was 26 months (range: 6-42 months). Clinical, laboratory and genotypic features of our patients are summarized in Table 1. Most $(80 \%)$ of the patients were male $(8 / 10)$ and $20 \%$ of them were female $(2 / 10)$. The median age of onset of symptoms was 3.6 months (range: 0-12 months) in IOPD patients. Hypotonicity was the most common symptom $(5 / 7 ; 83 \%)$, followed by respiratory distress $(5 / 7,83 \%)$. Cardiomyopathy $(6 / 7 ; 85 \%)$ and hypotonicity $(6 / 7 ; 85 \%)$ were the most common findings at presentation. Arrhythmia was seen in $66 \%$ of our patients (4/7). Two IOPD patients were diagnosed during the postnatal evaluation due to sibling history; one IOPD patient was diagnosed incidentally after detection of hypertrophic cardiomyopathy (HCM) and elevated muscle enzymes in the evaluation for congenital metabolic diseases during his admission with hemolytic anemia. Five of our 7 IOPD patients had been investigated for spinal muscular atrophy (SMA) before investigation for Pompe disease.
The median age of onset of LOPD patients was 8 years (1-23 years). The most common initial symptom was muscle weakness $(4 / 4 ; 100 \%)$ followed by fatigue $(3 / 4 ; 75 \%)$. None of our LOPD patients required the use of wheelchairs or invasive or noninvasive mechanical ventilators during follow-up. During the follow-up of our LOPD patients in different clinics, 3 patients were seen to have been followed up with a preliminary diagnosis of limb-girdle muscular dystrophy.

\section{GAA activity measurement and Creatine Kinase values}

GAA activites, analyzed from the dry blood samples of patients diagnosed with IOPD and LOPD, were determined as $0.12 \pm 0.16 \mathrm{nmol} / \mathrm{ml} /$ hour ( $\mathrm{N}: 1.1-4.02$ ) and $0.51 \pm 0.93 \mathrm{nmol} / \mathrm{ml} /$ hour, respectively. A statistically significant difference was found between the GAA activities of LOPD and IOPD patients (Table 2).

Serum creatine kinase (CK) levels were found to be high in all of our patients. Mean serum CK levels were $463 \pm 45.6$ in IOPD and $521 \pm 59.3 \mathrm{IU} / \mathrm{I}(\mathrm{N}:<175)$ in LOPD patients. No statistically significant difference was found between LOPD and IOPD patients.

\section{GAA mutations}

Pathogenic GAA variants detected in our patients were studied as 20 alleles in total from 10 patients listed in Table 3. In 80\% (8/10) of our patients, kinship was found between parents. Patient 2-3, and patient 5-6 were siblings. Homozygous pathogenic variant was detected in 8 patients and compound

Table 1. Clinical feaures of patients.

\begin{tabular}{|c|c|c|c|c|c|c|c|c|c|c|c|}
\hline \multirow[b]{2}{*}{ Patient } & \multirow[b]{2}{*}{ Gender } & \multirow[b]{2}{*}{$\begin{array}{l}\text { Age at } \\
\text { onset }\end{array}$} & \multirow[b]{2}{*}{$\begin{array}{c}\text { Age at } \\
\text { diagnosis }\end{array}$} & \multicolumn{2}{|c|}{ Cardiomyopathy } & \multirow[b]{2}{*}{ Dysrithmia } & \multirow[b]{2}{*}{ Hypotonicity } & \multirow[b]{2}{*}{$\begin{array}{c}\text { Muscle } \\
\text { weakness }\end{array}$} & \multirow[b]{2}{*}{$\begin{array}{c}\text { Disease } \\
\text { classification }\end{array}$} & \multirow[b]{2}{*}{$\begin{array}{l}\text { Survival } \\
\text { Time }\end{array}$} & \multirow[b]{2}{*}{$\begin{array}{c}\text { Current } \\
\text { Age }\end{array}$} \\
\hline & & & & Hypertrophic & Dilated & & & & & & \\
\hline 1 & Male & 0 months & 3 months & + & - & + & + & - & IOPD & 8 months & - \\
\hline 2 & Male & 4 months & 12 months & + & - & - & + & - & IOPD & 12 months & - \\
\hline 3 & Male & 0 months & 0 months & + & - & - & + & - & IOPD & - & 4 years \\
\hline 4 & Male & 2 months & 2 months & + & - & + & - & - & IOPD & - & 3.5 years \\
\hline 5 & Male & 0 months & 6 months & + & - & + & + & - & IOPD & 9 months & - \\
\hline 6 & Male & 2 months & 6 months & - & - & - & - & - & IOPD & - & 13 months \\
\hline 7 & Female & 0 months & 1 month & - & + & + & + & - & IOPD & - & 8 months \\
\hline 8 & Male & 5 years & 9 years & + & - & + & - & + & LOPD & - & 13 years \\
\hline 9 & Female & 23 years & 24 years & - & - & - & - & + & LOPD & - & 26 years \\
\hline 10 & Male & 8 years & 17 years & - & - & - & - & + & LOPD & - & 19 years \\
\hline
\end{tabular}


Table 2. Molecular genetic findings of patients .

\begin{tabular}{|c|c|c|c|c|c|c|c|}
\hline Patient & Allele 1 & Location & Allele 2 & Location & Variant classification & $\begin{array}{l}\text { CPK at diagnosis } \\
(\mathrm{IU} / \mathrm{L})(\mathrm{N}:<175)\end{array}$ & $\begin{array}{c}\text { GAA enzyme activity } \\
\text { (nmol/ml/saat) (N:1.-4.02) }\end{array}$ \\
\hline 1 & c.896 T>C p.(Leu299Arg) & Exon 5 & c.896 T>C p.(Leu299Arg) & Exon 5 & B (Potentially less severe) & 345 & 0,24 \\
\hline 2 & c.258dup p.(Asn87GInfsX9) & Exon 2 & c.258dup p.(Asn87GInfsX9) & Exon 2 & A (very severe) & 521 & 0,11 \\
\hline 3 & c.258dup p.(Asn87GInfsX9) & Exon 2 & c.258dup p.(Asn87GInfsX9) & Exon 2 & A (very severe) & 672 & 0,12 \\
\hline 4 & c.896 T>C p.(Leu299Arg) & Exon 5 & c.896 T>C p.(Leu299Arg) & Exon 5 & B (Potentially less severe) & 456 & 0,26 \\
\hline 5 & c.896 T>C p.(Leu299Arg) & Exon 5 & c.896 T>C p.(Leu299Arg) & Exon 5 & B (Potentially less severe) & 389 & 0,21 \\
\hline 6 & c.896 T>C p.(Leu299Arg) & Exon 5 & c.896 T>C p.(Leu299Arg) & Exon 5 & B (Potentially less severe) & 474 & 0,1 \\
\hline 7 & c.2019C>A p.(Asn673Lys) & Exon 14 & c.2019C>A p.(Asn673Lys) & Exon 14 & Unknown & 567 & 0.1 \\
\hline 8 & c.1237 G>T p.(Asp413Tyr) & Exon 8 & c. $-32-13 T>G$ & Intron 1 & Unknown/ D (potentially mild) & 651 & 0,42 \\
\hline 9 & c. $418 \mathrm{~A}>\mathrm{T}$ & Exon 2 & c. $-32-13 T>G$ & Intron 1 & Unknown/ D (potentially mild) & 497 & 0,36 \\
\hline 10 & c. $-32-13 T>G$ & Intron 1 & c. $-32-13 T>G$ & Intron 1 & $\mathrm{D}$ (potentially mild) & 532 & 0,28 \\
\hline
\end{tabular}

heterozygous variant in 2 patients.

Of the 20 alleles studied, 12 were identified as missense $(12 / 20,60 \%), 4$ as splice-sites $(4 / 20 ; 20 \%)$, and 4 as frameshift $(4 / 20,20 \%)$. The most common variant was C.896 T> C (8/14, 57.1\%) and the second most common mutation was c.258dup (4/20, 20\%). Of the 6 variants we identified, 3 had already been described in the literature; while c.1237G> T (p. Asp413Tyr), c.2019 C> A(P.asn673lys) , c.418A> T (p.Asn140Tyr) variants were detected for the first time. Variants C.1237 G>T and c.418 A>T were classified as variant of uncertain significance (VOUS) according to the ACMG classification; and c.2019 C>A variant was classified as 'likely pathogenic', but all 3 variants were considered as pathogenic because of their location in a highly conserved region among species and interpretation by in-silico prediction programs as damaging.

\section{Enzyme Replacement Therapy}

Three of our IOPD patients received ERT at a dose of $20 \mathrm{mg} / \mathrm{kg} / 2$ weeks and 4 patients at a dose of 20 $\mathrm{mg} / \mathrm{kg} /$ week. One patient died without receiving ERT. CRIM status could not be evaluated in our patients. Desensitization was performed in one patient due to anaphylaxis developed during ERT.

\section{DISCUSSION}

The phenotype and genotype relationship of Pompe disease in different ethnic groups has been discussed.(16-19) There are no studies investigating phenotype-genotype characteristics of IOPD patients in our country.
- When the initial symptoms were evaluated in two different groups, hypotonicity was the most and respiratory distress was the second most frequently seen disorders in IOPD patients. The first symptom was most frequently muscle weakness in LOPD patients. When the initial symptoms are compared, hypotonicity is seen in IOPD and muscle weakness in LOPD. While noninvasive mechanical ventilator support was required in 3 IOPD patients $(3 / 7 ; 45 \%)$, respiratory support was not required in LOPD patients during followup. Most (90\%) of our IOPD patients whereas $33 \%(1 / 3)$ of LOPD patients had HCM at the time of diagnosis,. Arrhythmia, which is an important part of cardiac involvement in Pompe disease, was seen in $57 \%(4 / 7)$ of IOPD and in $33 \%(1 / 3)$ of LOPD patients. Our initial symptoms were evaluated to be consistent with the literature. However, wheelchair use was not seen in our LOPD group. The lack of need for wheelchair and respiratory support in our patients can be explained by the early initiation of ERT. In the literature, in the natural course studies performed before ERT, wheelchairs was used in $38 \%$ and respiratory support in $31 \%$ of the patients with LOPD. All of our LOPD patients had muscle weakness at the time of diagnosis. All 3 patients received initial diagnosis of LGMD and long-term follow-up. Pompe disease should be considered in patients followed up with a preliminary diagnosis of LGMD who have not been definitely diagnosed by molecular genetic methods.

When the diagnostic process of the patients was evaluated, two patients (patient 4 and patient 6) were diagnosed based on sibling history, and one 
patient (patient 4) was diagnosed after incidental detection of HCM during the investigation of the etiology of hemolytic anemia. All three of these patients were diagnosed early in life and enzyme replacement therapy was started in the early period. During the follow-up with ERT of all three patients, $\mathrm{HCM}$ regressed completely. When the literature is examined, it is observed that HCM can completely return to normal in $46 \%$ of patients started on ERT during the early stage of the disease ${ }^{(20)}$.

To date, around 600 pathogenic variants have been detected in the GAA gene (http://www.hgmd.cf.ac. uk/ac/gene.php?gene=ga to). GAA pathogenic variants, namely, exon 2 with start codon, exon 10 and 11 with enzyme catalytic domain and exon 14 with a highly conserved region among species are seen in three critical regions.(21) Six different variants detected in our patients were distributed in intron 1 , exon 2, exon 5, exon 8 and exon 14. c.1237G $>T$ (p. Asp413Tyr), c.2019 C>A (p.Asn673Lys), c.418A>T (p. Asn140Tyr), variants were detected for the first time in our study. The variant c.2019 C>A (p.Asn673Lys) was detected only in exon 14 in the region highly conserved among species. All of these variants are missense variants (Tables 1, 2).

When the variant types of patients were evaluated out of 20 alleles, 12 missense $(12 / 20,60 \%), 4$ splicesite $(4 / 20 ; 20 \%)$, and 4 frameshift $(4 / 20,20 \%)$ variants were detected While missense variants are commonly thought to have a better course than nonsense and frameshift variants that lead to premature stop codon; it is difficult to make clear comments on other than c.-32-13T>G variant. In their study towards resolving the confusion in this regard, Kroos et al. divided the detected variants in 6 groups. $(17,22-24)$ The most severe variants are CRIM negative (class A, very severe), followed by classes ending in class $F$ according to severity. c.258dup variant class A, c.896T $>C$ variant class B (potentially less severe), $c$. da-32-13T>Gclass $D$ (potentially mild) were detected in our patients. The classification of the newly identified 3 variants is not yet known. CRIM status is not known in our patients due to the fact that CRIM status is needed to be determined before ERT for technical reasons, because of the necessity of waiting for sample transport material to become available and necessity of urgent ERT initiation to the patients. For this reason, classification could not be made especially in newly identified variants, since CRIM status, which is the first condition in the classification of Kroos et al., could not have been checked. Sibling patients 2 and 3, who carried c.258dup variant, a class A variant, homozygously, showed very different clinical courses. When the patient 2 was brought to the hospital at the age of 12 months due to hypotonicity that started at 4 months of age, HCM was detected and the diagnosis of Pompe disease was made very quickly. However, due to immigrant status of the patient, ERT could not be provided with health insurance and the patient died very quickly before ERT could be started. Patient 3 was diagnosed with Pompe disease in the first month of its life and ERT could be started immediately. At present 4-year-old patient's HCM findings completely regressed and neuromotor development is close to normal. It is clear that the clinical difference between the two siblings is due to the early start of ERT.

The phenotype-genotype correlation of Pompe disease varies considerably. Clinics of siblings are very important in determining phenotype- genotype correlation. While sibling concordance in lateonset Pompe disease has been investigated, sibling concordance in early-onset Pompe disease has not been addressed much. In our patient group, 4 patients ( 2 families) were siblings. In the concordance study conducted by Smith et al., it was demonstrated that clinics of the siblings were very similar ${ }^{(25)}$. When the prognosis and clinical features of our patients were compared among siblings, it was found that the sibling after the proband had better clinical progression due to index case being diagnosed late and treatment being started in the newborn period with siblings detected in the family screening. When patients 1, 4, 5 and 6, who had class B c.896 C> A variant which was the most common in our series, were evaluated among themselves, there was no significant difference in the initial symptoms of the disease, age at onset, enzyme activity and ERT start time; though differences were observed in clinical findings and prognosis. This suggests that there may be other factors or other modifying genes in the same gene, other than the GAA gene variant in Pompe disease. Filippi et al. suggested that polymorphisms in the ACE gene affect the prognosis of the disease (22). 


\section{CONCLUSION}

Pompe disease is the first metabolic myopathy in which corrective treatment is started. Since the start of the active use of ERT, there has been an improvement in the course of the disease and a significant increase in the number of surviving patients. Therefore, it is one of the diseases where early diagnosis is vital. While the phenotype-genotype is not known to be well correlated, it is of great importance in predicting prognosis and response to treatment as in all congenital metabolic diseases. Although the molecular genetic features of LOPD patients have been presented in the literature, there are limited studies about the molecular genetic features of IOPD patients Our study is one of the first studies in our country to discuss the molecular and clinical features of both LOPD and IOPD patients.

Ethics Committee Approval: Approval was obtained from the Izmir Katip Çelebi University NonInterventional Clinical Research Ethics Committee (01/12/2018, 31829978-050.01.04-E.1700086095).

\section{Conflict of Interest:}

Funding: The authors declares that have no financial support.

Informed Consent: Informed consent was obtained from the patients' parents.

\section{REFERENCES}

1. Van der Ploeg AT, Reuser AJ. Pompe's disease. Lancet. 2008;372(9646):1342-53. https://doi.org/10.1016/S0140-6736(08)61555-X

2. Kroos $M$, Hoogeveen-Westerveld $M$, van der Ploeg $A$, Reuser AJ. The genotype-phenotype correlation in Pompe disease. Am J Med Genet C Semin Med Genet. 2012;160c(1):59-68. https://doi.org/10.1002/ajmg.c.31318

3. Kishnani PS, Hwu WL, Mandel H, Nicolino M, Yong F, Corzo D. A retrospective, multinational, multicenter study on the natural history of infantile-onset Pompe disease. J Pediatr. 2006;148(5):671-6. https://doi.org/10.1016/j.jpeds.2005.11.033

4. Mclntosh PT, Hobson-Webb LD, Kazi ZB, Prater SN, Banugaria SG, Austin S, et al. Neuroimaging findings in infantile Pompe patients treated with enzyme replacement therapy. Mol Genet Metab. 2018;123(2):85-91. https://doi.org/10.1016/j.ymgme.2017.10.005

5. Lim JA, Li L, Raben N. Pompe disease: from pathophysiology to therapy and back again. Front Aging Neurosci. 2014;6:177.

https://doi.org/10.3389/fnagi.2014.00177

6. Kishnani PS, Steiner RD, Bali D, Berger K, Byrne BJ, Case LE, et al. Pompe disease diagnosis and management guideline. Genet Med. 2006;8(5):267-88.

https://doi.org/10.1097/01.gim.0000218152.87434.f3

7. Pellegrini N, Laforet $P$, Orlikowski D, Pellegrini M, Caillaud C
Eymard B, et al. Respiratory insufficiency and limb muscle weakness in adults with Pompe's disease. Eur Respir J. 2005;26(6):1024-31.

https://doi.org/10.1183/09031936.05.00020005

8. Gungor D, Reuser AJ. How to describe the clinical spectrum in Pompe disease? Am J Med Genet A. 2013;161A(2):399-400. https://doi.org/10.1002/ajmg.a.35662

9. Kishnani PS, Corzo D, Leslie ND, Gruskin D, Van der Ploeg A, Clancy JP, et al. Early treatment with alglucosidase alpha prolongs long-term survival of infants with Pompe disease. Pediatr Res. 2009;66(3):329-35. https://doi.org/10.1203/PDR.0b013e3181b24e94

10. van Gelder CM, Poelman E, Plug I, Hoogeveen-Westerveld M, van der Beek N, Reuser AJJ, et al. Effects of a higher dose of alglucosidase alfa on ventilator-free survival and motor outcome in classic infantile Pompe disease: an open-label singlecenter study. J Inherit Metab Dis. 2016;39(3):383-90. https://doi.org/10.1007/s10545-015-9912-y

11. Bali DS, Goldstein JL, Rehder C, Kazi ZB, Berrier KL, Dai J, et al. Clinical laboratory experience of blood crim testing in infantile pompe disease. Mol Genet Metab Rep. 2015;5:76-9. https://doi.org/10.1016/j.ymgmr.2015.10.012

12. Banugaria SG, Prater SN, Ng YK, Kobori JA, Finkel RS, Ladda RL, et al. The impact of antibodies on clinical outcomes in diseases treated with therapeutic protein: lessons learned from infantile Pompe disease. Genet Med. 2011;13(8):729-36. https://doi.org/10.1097/GIM.0b013e3182174703

13. van Gelder CM, Hoogeveen-Westerveld M, Kroos MA, Plug I, van der Ploeg AT, Reuser AJ. Enzyme therapy and immune response in relation to CRIM status: the Dutch experience in classic infantile Pompe disease. J Inherit Metab Dis. 2015;38(2):305-14. https://doi.org/10.1007/s10545-014-9707-6

14. Landis JL, Hyland H, Kindel SJ, Punnoose A, Geddes GC Pompe disease treatment with twice a week high dose alglucoside alfa in a patient with severe dilated cardiomyopathy. Mol Genet Metab Rep. 2018;16:1-4. https://doi.org/10.1016/j.ymgmr.2018.05.002

15. Orsini JJ, Martin MM, Showers AL, et al. Lysosomal storage disorder 4+1 multiplex assay for newborn screening using tandem mass spectrometry: Application to a small-scale population study for five lysosomal storage disorders. Clin Chim Acta. 2012;413(15-16):1270-3. https://doi.org/10.1016/j.cca.2012.04.012

16. Laforet $P$, Nicolino $M$, Eymard $B$, et al. Juvenile and adultonset acid maltase deficiency in France: Genotype-phenotype correlation. Neurology. 2000;55(8):1122-8. https://doi.org/10.1212/WNL.55.8.1122

17. Kroos MA, Van der Kraan M, Van Diggelen OP, et al. Glycogen storage disease type II: frequency of three common mutant alleles and their associated clinical phenotypes studied in 121 patients. J Med Genet. 1995;32:836-7. https://doi.org/10.1136/jmg.32.10.836-a

18. Montalvo AL, Bembi B, Donnarumma $\mathrm{M}$, et al. Mutation profile of the GAA gene in 40 Italian patients with late onset glycogen storage disease type II. Hum Mutat. 2006;27(10):9991006. https://doi.org/10.1002/humu.20374

19. Gort L, Coll MJ, Chabás A. Glycogen storage disease type II in Spanish patients: High frequency of c.1076-1G>C mutation. Mol Genet Metab. 2007;92(1-2):183-7. https://doi.org/10.1016/j.ymgme.2007.05.011

20. Desai AK, Walters CK, Cope HL, Kazi ZB, DeArmey SM, Kishnani PS. Enzyme replacement therapy with alglucosidase alfa in Pompe disease: Clinical experience with rate escalation. Mol Genet Metab. 2018;123(2):92-6. https://doi.org/10.1016/j.ymgme.2017.12.435

21. Fernandez-Hojas R, Huie ML, Navarro C, et al. Identification of six novel mutations in the acid alpha-glucosidase gene in three Spanish patients with infantile onset glycogen storage disease type II (Pompe disease). Neuromuscul Disord. 
2002;12(2):159-66

https://doi.org/10.1016/S0960-8966(01)00247-4

22. De Filippi P, Saeidi K, Ravaglia S, Dardis A, Angelini C, et al. Genotype-phenotype correlation in Pompe disease, a step forward. Orphanet J Rare Dis. 2014;9:102. https://doi.org/10.1186/s13023-014-0102-z

23. Bekircan-Kurt CE, Günes HN, Yildiz FG, Saka E, Tan E, ErdemÖzdamar S. New mutations and genotype-phenotype correlation in late-onset Pompe patients. Acta Neurol Belg. 2017;117(1):269-71.

https://doi.org/10.1007/s13760-016-0738-7
24. Pittis MG, Donnarumma $M$, Montalvo $A L$, Dominissini $S$, Kroos $\mathrm{M}$, Rosano $\mathrm{C}$, et al. Molecular and functional characterization of eight novel GAA mutations in Italian infants with Pompe disease. Hum Mutat. 2008;29:e27-36. https://doi.org/10.1002/humu.20753

25. Smith WE, Sullivan-Saarela JA, Li JS, Cox GF, Corzo D, Chen YT, et al. Sibling phenotype concordance in classical infantile Pompe disease. Am J Med Genet A. 2007;143A(21):2493501.

https://doi.org/10.1002/ajmg.a.31936 